\title{
ELINIKÄINEN OPPIMINEN SANOISTA TEOIKSI
}

\author{
Kari Purhonen
}

\begin{abstract}
Koulutus, tiede ja teknologia, yrittäjyyden ja omatoimisuuden lisääminen, laatu sekä kansainvälisyys siinä yritysjohtajien luettelemia menestyksen avaimia .
\end{abstract}

"Meillä lienee vain yksi tie hyvinvointimme takaamiseen. Se on tietämisen ja taitamisen tason jatkuva kohottaminen." Näin totesi presidentti Urho Kekkonen uuden vuoden puheessaan 1980 .

Samaa mieltä olivat suomalaiset yritysjohtajat vuonna 1997 julkistetun EVAn tutkimuksen mukaan. Siinä kartoitettiin mm. yritysjohtajien näkemyksiä menestyksen eväistä. Kun heiltä kysyttiin, mitkä asiat kantavat maatamme tästä eteenpäin, kärkeen nousivat koulutus, tiede ja teknologia, yrittäjyyden ja omatoimisuuden lisääminen, laatu sekä kansainvälisyys. Lähes sata prosenttia yritysjohtajista piti koulutukseen sekä tieteeseen ja teknologiaan panostamista joko erittäin tärkeänä tai melko tärkeänä.

Elinikäinen oppiminen tavoitteena on ollut monin tavoin esillä. Myös suomalainen teollisuus on havainnut, että sen palveluksessa olevat ja sinne tulevat ihmiset on saatava huolehtimaan ammatillisesta kasvustaan. Jatkuva oppiminen on saatava juhlapuheista ja teoriasta käytäntöön.

$\mathrm{N}$ uorten koulutus on kansainvälisestikin verrattuna hyvä. Sen sijaan ikääntyneemmän väestön pohjakoulutus on selvästi heikompaa. Toisaalta selvitykset yritysten osaamistarpeista paljastavat, että jatkossa tarvitaan korkeasti koulutettua henkilökuntaa erityisesti tieto- ja elektroniikkateollisuuteen. Tarve ylittää selvästi nykyisen koulutustarjonnan.

\section{OSAAMISTA, OSAAMISTA}

Noin puolet $\mathrm{mm}$. teollisuuden rekrytoinneista kohdistuu jatkossa ammattikorkea- tai yliopistotutkinnon suorittaneisiin. Suurin puute on insinööreistä tietotekniikan, tietoliikennetekniikan sekä elektroniikan aloilla. Ellei henkilöstön tarjonta vastaa kysyntää, vaarana on, että nämä teollisuuden alat menettävät kasvupotentiaalia. Tämä taas heijastuisi välittömästi koko teollisuuden ja siten koko yhteiskunnan kasvunäkymiin.

Opetusministeriö on tarttunut härkää sarvista ja on lisäämässä runsaasti tietoteollisuuden tarvitsemia koulutus- ja tutkimuspanostuksia. Se ei kuitenkaan myöntänyt kokeilulupaa teollisuuden verkostomaiselle ammattikorkeakoululle, joka olisi toiminut AEL:ssa yhteistyössä Espoon-Vantaan teknillisen ammattikorkeakoulun ja JTO:n 
kanssa. Samaan aikaan joukko kansanopistoja tuon luvan sai.

Myös työministeriö on kantamassa vastuunsa panostamalla erityisesti muuntokoulutukseen, jossa juuri valmistuneita, työssäolevia tai työttömiä insinöörejä koulutetaan kasvualoille. Muuntokoulutuksen lisääminen - jos mikä - turvaa osaltaan sen, että kasvualoille saadaan nopeasti ammattitaitoista henkilöstöä. Nämä rohkeat ja kauaskantoiset päätökset vahvistavat omalta osaltaan kasvualojen investointiedellytyksiä Suomessa.

\section{KOULUTUS EI OLE SOSIAALINEN ETU}

Teollisuus on kantanut hyvin huolta henkilöstöstään. Se näkyy monien täydennyskoulutuslaitosten koulutusvolyymin jatkuvana kasvuna. Panokset henkilöstön kehittämiseen ovat teollisuusmaiden huippuluokkaa. Olemme selvästi OECD-maiden keskiarvon yläpuolella. Investoinnit "ihmiseen" ovat jo yli 2000 miljoonaa markkaa. Laman syvimpinä vuosina panostus oli runsas 1000 miljoonaa.

$\mathrm{T}$ eollisuuden kannalta koulutuksen ongelma ei ole omien koulutuspanostusten puute. Henkilöstökin on yleensä hyvin motivoitunutta hankkimaan lisäkoulutusta. Perusongelmana on julkisten koulutuspanosten suuntaaminen, joka näkyy siten, että meillä on suuresta työttömyydestä huolimatta samanaikainen pula osaavista ihmisistä.

Koulutustarpeen jatkuva kasvu ja nopeat muutokset osoittavat, että esteet elinikäisen oppimisen tieltä on raivattava. Käytännössä se edellyttää, että uusien menetelmien käyttöä oppimisessa lisätään. Tähän suovat mahdollisuuden kehittyvä tietotekniikka, multimedia, virtuaalitodellisuus yms. On avattava mahdollisuudet eritasoisten ja poikkitieteellisten tutkintojen suorittamiseen. Lisäksi tarvitaan opintosuorituspankkeja, kannustejärjestelmiä ja oppimisen tulosten arviointijärjestelmiä.

Koulutus ei saa olla kuitenkaan pelkästään sosi- aalinen etu, vaan tavoitteellista toimintaa osaamistarpeiden kehittämiseksi. Rahalla motivointi ei riitä, eikä kukaan voi oppia toisen puolesta. Ihmisellä täytyy olla omaehtoinen vastuu oppimisestaan, halu oppia, oppimisen hinku.

\section{KOULUTUKSEN LAATUUN}

Tilastot vuodelta 1996 osoittavat, että pelkästään ammatilliseen aikuiskoulutukseen osallistui 830000 henkeä. Väestömäärään verrattuna luku on suurin OECD-maissa. Koska koulutusmäärät ovat OECD-maiden huippua, tulisi meidän vakavasti kiinnittää huomiota jatkossa opetuksen sisältöihin ja laatuun.

Tyydymme liian helposti keskinkertaisuuteen, kun voisimme nostaa rimaa. Tämä koskee kaikkea koulutusta varhaiskasvatuksesta korkeakouluja tiedepolitiikkaan saakka.

Koulutus on laadukasta silloin, kun sen avulla saavutetaan ne tavoitteet, jotka koulutukselle on asetettu. Muita laadukkaan koulutuksen ominaispiirteitä voisivat olla, että koulutus on tehokkaasti toteutettu, se työllistää, koulutusaika tavoitteisiin nähden on optimaalinen ja se motivoi myöskin lisäopintoihin. Myös koulutuskustannusten tulisi olla oikeassa suhteessa koulutuksen tavoitteisiin, sisältöihin ja kestoon.

Laadun ja tuloksellisuuden takaamiseksi tarvitsemme oppilaitoksiin ja korkeakouluihin laatusertifikaatteja. Oppilaitosten tulisi taata, että sieltä valmistuneet tai kurssin käyneet hallitsevat vaaditut tiedot, taidot ja asenteet. Kysymys on siis eräänlaisesta koulutuksen laaduntakuujärjestelmästä.

\section{ELINIKÄISEN OPPIMISEN ESTEET RAIVATTAVA}

Kaikki julkisen vallan toimenpiteet eivät ole kuitenkaan sopusoinnussa elinikäisen oppimisen periaatteen kanssa. Teollisuuden ammattikorkeakoulu ei saanut kokeilulupaa, vaikka tavoitteena oli nimenomaan työssäolevan väestön osaamistason kohottaminen kasvualoilla. 
Elokuun alussa 1998 voimaan tullut uusi yliopistolaki ei salli yritysten maksamaa tutkintoon johtavaa koulutusta henkilöstölleen siitäkään huolimatta, etteivät yritysedustajien paikat ole poissa nuorten koulutuksesta. Osallistujat on sitä ennen valittu normaalissa valintaprosessissa, joten rahalla tutkinnon ostamisesta ei ole kysymys.

$\mathrm{T}$ uorein rajoitus elinikäisen oppimisen toteuttamisesta käytännössä koskee oppisopimuskoulutuksena annettavaa ammatillista lisäkoulutusta. Ammattitutkintoon tai erikoisammattitutkintoon johtava lisäkoulutus on määrätty kaikilta osin määrällisen säätelyn piiriin. Ymmärrän hyvin, että kysymys on valtion taloudellisesta tilanteesta ja opetusministeriön painopisteiden asetannasta. Lisäkoulutuksena annettavan oppisopimuskoulutuksen volyymi on kasvanut odotettua enemmän, mikä tietenkin aiheuttaa myös kustannuksia.

Sanotaan, että koulutus maksaa, mutta halutaanko kokeilla tietämättömyyttä. Se maksaa varmasti enemmän.
$\mathrm{O}$ ppisopimuskoulutuksena toteutettu tutkintotavoitteinen lisäkoulutus on yhteiskunnalle edelleen ehdottomasti edullisin koulutusmuoto. Julkisen vallan panostus ammattitutkintoihin lienee koulutettavaa kohden alle 30000 markkaa, kun se kiinteämuotoisessa nousee lähemmäksi 50000 markkaa. Kun tähän lisätään pääomakustannukset, summa nousee helposti kolminkertaiseksi oppisopimuskoulutukseen verrattuna. Lisäksi yhteiskunta saa oppilaasta tuloja, koska useimmissa tapauksissa työnantaja maksaa koulutettavalle normaalin työehtosopimuksen mukaisen palkan.

Oppisopimuskoulutuksen vaihtoehdoksi tulee helposti työvoimapoliittinen aikuiskoulutus. Se edellyttää kuitenkin työttömyysuhkaa tai suoranaista työttömyyttä. Kustannukset nousevat yli 100000 markan vuodessa koulutettavaa kohden. Olisiko opetusviranomaisten ja poliittisten päättäjien sittenkin aihetta tarkistaa kantaansa? 